\title{
In vitro Antiproliferative and inhibition of oxidative DNA damage activities of $n$-butanol extract of Limonium bonduelli from Algeria
}

\author{
Amel Amrani ${ }^{1,2^{\star}}$ \\ http://orcid.org/0000-0003-1672-4065 \\ Amina Maya Lahneche ${ }^{1}$ \\ http://orcid.org/0000-0002-1200-1946 \\ Ouahiba Benaissa ${ }^{2}$ \\ https://orcid.org/0000-0001-6102-2383 \\ Nassima Boubekri ${ }^{1,2}$ \\ https://orcid.org/0000-0002-1739-8911 \\ Ibrahim Demirtaş ${ }^{3}$ \\ http://orcid.org/0000-0001-8946-647X
}

Fadila Benayache ${ }^{2}$

http://orcid.org/0000-0002-2282-6343

Samir Benayache ${ }^{2}$

http://orcid.org/0000-0003-2298-2466

Djamila Zama ${ }^{1,2}$

https://doi.org/10.3329/bjp.v13i1.34255

1Département de Biologie Animale, Faculté des Sciences de la Nature et de la Vie, Université Frères Mentouri Constantine, Route de Ain El Bey, Constantine, 25000, Algérie. ${ }^{2}$ Unité de Recherche Valorisation des Ressources Naturelles, Molécules Bioactives et Analyses Physicochimiques et Biologiques. Département de Chimie, Université Frères Mentouri Constantine, Route de Ain El Bey, Constantine, 25000, Algérie. ${ }^{3}$ Plant research Laboratory,Chemistry Department, Cankiri Karatekin University, Ballica Campus, 18100, Cankiri, Turkey. 
Received: 2017.12.08; Accepted: 2018.10.17.

\section{HIGHLIGHTS}

- L. bonduelli showed high phenolic and flavonoid contents

- It showed a broad-spectrum antioxidant properties including DNA protection

- It showed concentration-dependent antiproliferative effects

\section{- L. bonduelli is a rich source of natural antioxidants and anticancer agents}

Abstract: Plants are the main sources of natural antioxidants in the form of phenolic compounds, which help human beings to deal with oxidative stress, caused by free radical damage. For this reason, the present study was carried out to evaluate the antiproliferative, antioxidant and inhibition of oxidative DNA damage activities of $n$-butanol extract obtained from aerial parts of Limonium bonduelli. The antioxidant potential was determined using 1,1-diphenyl-2-picrylhydrazyl (DPPH) radical scavenging and inhibition of lipid peroxidation assay. Antiproliferative activity was evaluated using xCELLigence RTCA instrument on two tumor cell lines; HT-29 (human colon adenocarcinoma) and HeLa (human cervix carcinoma). DNA damage inhibition was evaluated using photolyzing 46966 plasmid. Also, total phenolic and total flavonoid contents were determined using a spectrophotometric method. Total phenolic (343 $\pm 0.05 \mu \mathrm{g} / \mathrm{mg}$ ) and flavonoid $(220.5 \pm 0.04 \mu \mathrm{g} / \mathrm{mg}$ ) were indicated as gallic acid and quercetin equivalents respectively. The extract exhibited significant IC50 values in lipid peroxidation $(\mathrm{IC} 50=181.18 \pm 0.65 \mu \mathrm{g} / \mathrm{mL})$ and DPPH radical scavenging assays (IC50 $=14.92 \pm 0.032 \mu \mathrm{g} / \mathrm{mL}$ ). The extract also partially protected 46966 plasmid DNA from free radical-mediated oxidative stress in a DNA damage inhibition assay and showed concentration-dependent antiproliferative effects. $n$-butanol extract of $L$. bonduelli is a rich source of natural antioxidants and anticancer agents. Keywords: Limonium bonduelli; Antioxidant activities; Antiproliferative activity; DNA protection.

\section{INTRODUCTION}

In recent years, there has been a great deal of attention toward the field of free radicals in biology is producing a medical revolution that promises a new age of health and disease management [1]. Free radicals, including reactive oxygen species (ROS) and reactive nitrogen species are generated by the human body by various endogenous systems, exposure to different physiochemical conditions, or pathological states, and have been implicated in the pathogenesis of many diseases [2]. Excessive production of ROS can lead to oxidative stress triggering damage in cell structures, including lipids, proteins and DNA. This damage may cause many disorders such as cancer [3]. Antioxidants prevent free radical induced tissue damage by preventing the formation of radicals, scavenging them, or by promoting their decomposition. Synthetic antioxidants are recently reported to be dangerous to human health. Thus the search for effective, nontoxic natural compounds with antioxidative activity has been intensified in recent years. In addition to endogenous antioxidant defense systems, consumption of dietary and plant-derived antioxidants appear to be a suitable alternative [4].

Plants with a long history of use in ethno- medicine can be a rich source of substances, such as polyphenols for the treatment of various chronic or infectious diseases [5]. 
Polyphenols are secondary metabolites of plants and are generally involved in defense against ultraviolet radiation or aggression by pathogens. In the last decade, there has been much interest in the potential health benefits of dietary plant polyphenols as antioxidant. Epidemiological studies and associated meta-analyses strongly suggest that long term consumption of diets rich in plant polyphenols offers protection against the development of cancers, cardiovascular diseases, diabetes, osteoporosis, neurodegenerative diseases [6] and skin disorders [3].

Limonium species (Plumbaginaceae) have caught up the interest of researchers due to flavonoids and other phenolic components. Numerous studies on different parts of this plant demonstrate various biological activities such as antioxidant potential, anticancer [7], antiinflammatory [8], antimicrobial 9 and hepatoprotective activities [10, 11].

Our phytochemical analysis of ethyl acetate extract from aerial parts of $L$. bonduelli revealed the presence of important secondary metabolites, flavonoids (eriodictyol, luteolin, apigenin) and 4-hydroxy-3-methoxy benzoic acid. The ethyl acetate extract of $L$. bonduelli and pure flavonoids, eriodictyol and luteolin showed strong antioxidant properties [12].

However, our literature survey revealed no published reports on the anticancer potential of $L$. bonduelli an endemic Saharan species. Thus, the present investigation aimed to explore the anticancer efficacy of $n$-butanol extract of aerial parts from $L$. bonduelli (Lestib.) Sauv. Et Vindt on two tumor cell lines; HT-29 (human colon adenocarcinoma) and HeLa (human cervix carcinoma) as well as its antioxidant and inhibition of oxidative DNA damage activities.

\section{MATERIAL AND METHODS}

\section{Material Chemicals}

Ascorbic acid, 1,1-Diphenyl-2-picrylhydrazyl (DPPH), $\mathrm{FeSO}_{4}$, folin-ciocalteu reagent, gallic acid, $\mathrm{H}_{2} \mathrm{O}_{2}$, sodium carbonate $\left(\mathrm{Na}_{2} \mathrm{CO}_{3}\right)$, thiobarbituric acid (TBA), trichloroacetic acid(TCA) and quercetin, were purchased from Sigma Chemical (St. Louis, MO). Dulbecco's modified eagle's medium (DMEM), fetal bovine serum and Penicillin-Streptomycin were purchased from Sigma (Germany). All other chemicals and solvents (analytical grade) were purchased from Fluka (French).

\section{Plant material and extraction}

Aerial parts of L. bonduelli (Lestib.) Sauv. Et Vindt (Plumbaginaceae) were collected on April 2011 at Mogheul near Bechar in the South West of Algeria. The voucher specimen was identified by Prof. Mohamed Kaabeche from university of Setif and was deposited at the Research Unity VARENBIOMOL under the reference: LB/236/04-11.

Air-dried and powdered aerial parts (leaves and flowers, $1500 \mathrm{~g}$ ) of $L$. bonduelli were macerated at room temperature with $\mathrm{MeOH}-\mathrm{H}_{2} \mathrm{O}(70: 30, \mathrm{v} / \mathrm{v})$ for $24 \mathrm{~h}$, three times. After filtration, the combined filtrates were concentrated in vacuum (up to $35^{\circ} \mathrm{C}$ ), the remaining solution $(400 \mathrm{~mL})$ was dissolved in distilled $\mathrm{H}_{2} \mathrm{O}(600 \mathrm{~mL})$ under magnetic stirring and maintained at $4^{\circ} \mathrm{C}$ for one night to precipitate a maximum of chlorophylls. After filtration, the resulting solution was extracted successively with $\mathrm{CHCl}_{3}$, EtOAc and $n$-butanol. The organic phases were dried with $\mathrm{Na}_{2} \mathrm{SO}_{4}$, filtered using common filter paper and concentrated in vacuum $\left(35^{\circ} \mathrm{C}\right)$ to obtain the following extracts: $\mathrm{CHCl}_{3}(1.5 \mathrm{~g})$, EtOAc $(13 \mathrm{~g})$ and $n-\mathrm{BuOH}(42$ g) 12.

\section{Determination of Total Phenolic Content}

The total phenolic content was determined using the Folin-Ciocalteu colorimetric method described by Singleton et al. (1999) [13]. Briefly, $20 \mu \mathrm{L}$ of sample were diluted with $1580 \mu \mathrm{L}$ of distilled water and then mixed with $100 \mu \mathrm{L}$ of $2 \mathrm{~N}$ Folin-Ciocalteu reagents. The contents were vortexed for $10 \mathrm{sec}$ and then left to stand at room temperature for $6 \mathrm{~min}$ before the reaction was stopped by adding $300 \mu \mathrm{L} 20 \%(\mathrm{w} / \mathrm{v})$ sodium carbonate solution. The mixture was then incubated at $20^{\circ} \mathrm{C}$ for 2 hours. The solution absorbance was measured at 
$765 \mathrm{~nm}$. Gallic acid concentrations ranging from $50-500 \mu \mathrm{g} / \mathrm{mL}$ were prepared and the calibration curve was obtained using a linear fit $\left(R^{2}=0.991\right)$. The samples were analyzed in triplicate. The concentration of total phenolic compounds was determined as $\mu \mathrm{g}$ of gallic acid equivalents (GAE) per $1 \mathrm{mg}$ of extract.

\section{Determination of Total Flavonoid Content}

The total flavonoids were estimated by the aluminum chloride method described by Wang et al. (2008) [14]. Briefly, $500 \mu \mathrm{L}$ of the sample, $500 \mu \mathrm{L}$ of $\mathrm{AlCl}_{3}(2 \%)$ methanol solution was added. The absorbance measured at $420 \mathrm{~nm}$ after $1 \mathrm{~h}$ incubation at room temperature. Quercetin concentrations ranging from 0 to $1200 \mu \mathrm{g} / \mathrm{mL}$ were prepared and the standard calibration curve obtained using a linear fit $\left(R^{2}=0.990\right)$. The samples were analyzed in triplicate. Flavonoid content was calculated as $\mu \mathrm{g}$ of quercetin equivalents (QE) per $1 \mathrm{mg}$ of extract.

\section{Free Radical DPPH Scavenging Assay}

The DPPH assay was carried out according to the procedure of Braca et al. (2001) [15], with minor modifications. In this study, different volumes $(1,2.5,5,10,20,30,50$ and 75 $\mu \mathrm{g} / \mathrm{mL})$ of the extract were mixed with a methanolic solution of DPPH radical $(0.004 \%, 3 \mathrm{~mL})$. The mixture was kept in the dark. 30 min later, the absorbance was measured at $517 \mathrm{~nm}$. The free radical scavenging activity is expressed as the inhibition percentage of free radicals by the sample and calculated using following the formula:

$\%$ of DPPH radical scavenging effect $=\left[\left(\mathrm{A}_{\text {control }}-\mathrm{A}_{\text {sample }}\right) / \mathrm{A}_{\text {control }}\right] \times 100$

Where $A$ control is the absorbance of control and $A$ sample is the absorbance of sample at $517 \mathrm{~nm}$.

The $\mathrm{IC}_{50}$ (the concentration of antioxidant which eliminate $50 \%$ of DPPH radicals) was defined for the extract and control standard antioxidant (vitamin $\mathrm{C}$ ). The study was carried out in triplicate at each concentration $(n=3)$.

\section{Assays of lipid peroxidation using vitellus}

The inhibition of lipid peroxidation was determined by quantification of MDA decomposed from the lipid peroxide, which is based on the egg vitellus reacting with thiobarbituric acid. For the in vitro study, the fresh vitellus was dissected and homogenized in ice cold PSB $(20 \mathrm{mM}, \mathrm{pH} 7.4)$ to produce a $10 \%$ homogenate $(\mathrm{v} / \mathrm{v})$. The homogenate was centrifuged at $4000 \mathrm{rpm}$ for $20 \mathrm{~min}$ to remove precipitation. $1 \mathrm{~mL}$ aliquots of the supernatant were incubated with the extract in the presence of $\mathrm{FeSO}_{4}(0.07 \mathrm{M})$ at $37^{\circ} \mathrm{C}$ for $1 \mathrm{~h}$. The reaction was stopped by the addition of $1 \mathrm{~mL}$ trichloroacetic acid (TCA, 20\%, w/v) and 1.5 $\mathrm{mL}$ thiobarbituric acid (TBA, 1\%, w/v) in succession, and the solution was then heated at $100^{\circ} \mathrm{C}$ for $15 \mathrm{~min}$. After centrifugation at $4000 \mathrm{rpm}$ for $20 \mathrm{~min}$ to remove precipitated protein, the color of the complex was detected at $532 \mathrm{~nm}$. The control group was run in parallel without sample under similar conditions, except that $1 \mathrm{~mL}$ trichloroacetic acid (TCA, $20 \%$, $\mathrm{w} / \mathrm{v}$ ) was added before incubation and all measurements were done in triplicate. The lipid peroxidation scavenging activity $(\mathrm{K} \%)$ was calculated by the following equation:

$K(\%)=\left[\left(A_{\text {control }}-A_{\text {sample }}\right) / A_{\text {control }}\right] \times 100$

Where $A$ control is the absorbance of control and $A$ sample is the absorbance of sample [16].

\section{DNA damage inhibition efficiency}

The potential of $n$-butanol extract of $L$. bonduelli to inhibit DNA damage was tested by photolyzing 46966 plasmid DNA (extracted from Escherichia coli) via UV radiation in the presence of $\mathrm{H}_{2} \mathrm{O}_{2}$ and performing agarose gel electrophoresis with the irradiated DNA17. Into two polyethylene's micro centrifuge tubes, $1 \mu \mathrm{L}$ aliquots of 46966 plasmid $(0.2 \mu \mathrm{g} / \mathrm{mL})$ were added, followed by $50 \mu \mathrm{g}$ of $n$-butanol extract in one of the two tubes without the other which the irradiated control. Then $4 \mu \mathrm{L}$ of $3 \% \mathrm{H}_{2} \mathrm{O}_{2}$ was added into the two tubes, which were then placed directly on the surface of a UV transilluminator $(300 \mathrm{~nm})$ during $10 \mathrm{~min}$ at 
room temperature. In another tube, $1 \mu \mathrm{L}$ aliquot of 46966 plasmid DNA was placed and served as the non-irradiated control. All the samples were run on $1 \%$ agarose gel and then photographed using a Lourmat gel imaging system (Vilber) [17].

\section{Evaluation of the anticancer activity using xCELLigence system}

\section{Cell culture and preparation of Cell Suspension}

HT-29 (human colon adenocarcinoma) and HeLa (human cervix carcinoma) cells were grown in Dulbecco's modified eagle's medium (DMEM, Sigma), supplemented with 10\% $(\mathrm{v} / \mathrm{v})$ fetal bovine serum (Sigma, Germany) and 2\% Penicillin-Streptomycin (Sigma, Germany) at $37^{\circ} \mathrm{C}$ in a $5 \% \mathrm{CO}_{2}$ humidified atmosphere. Cells lines in the culture flask were detached from bottom of flask by $10 \mathrm{~mL}$ Trypsin-EDTA solution. After detachment, $10 \mathrm{~mL}$ of medium was added into the flask and mixed thoroughly. This suspension was transferred to Falcon tubes and centrifuged at $600 \mathrm{rpm}$ for $5 \mathrm{~min}$.

After removing the supernatant, $5 \mathrm{~mL}$ of medium was added to Falcon tube and mixed carefully. Cell concentration of this cell suspension was measured by CEDEX HiRes Cell Counter which uses Trypan Blue [18].

\section{Preparation of E-Plate 96 and treatment}

$50 \mu \mathrm{L}$ of medium was added into each well of E-Plate 96 . The plate was incubated in the hood, then in the incubator for $15 \mathrm{~min}$ in each time. After this period, the E-Plate 96 was inserted to the RTCA-SP station and a background measurement were performed. Then $100 \mu \mathrm{L}$ of the cell suspension $\left(2.5 \times 10^{4}\right.$ cells $\left./ 100 \mu \mathrm{L}\right)$ was added into the wells, except in the last three wells were only $100 \mu \mathrm{L}$ of medium was added to check if there would be an increase from culture medium. The plate was left in the hood for $30 \mathrm{~min}$, and then inserted into the xCELLigence station in the incubator. A measurement was performed for $80 \mathrm{~min}$. Extract was dissolved in DMSO to a final concentration of $20 \mathrm{mg} / \mathrm{mL}$. $25 \mu \mathrm{L}$ of this solution was mixed with $475 \mu \mathrm{L}$ of medium. The extract solutions $(50,20$ and $10 \mu \mathrm{L}$ equivalent to 250,100 and $50 \mu \mathrm{g} / \mathrm{mL}$ concentrations, respectively) were added into the wells and the final volumes were completed to $200 \mu \mathrm{L}$ with medium. No extract solution was added into control and medium wells. Then the plate was inserted to xCELLigence station in the incubator and a measurement for $48 \mathrm{~h}$ or $72 \mathrm{~h}$ was started [18].

\section{Statistical analysis}

All data are expressed as the mean \pm SD of triplicate measurements. The statistically significant differences between mean values at the level of significance $(P<0.05)$ were evaluated by the paired t test in SPSS (version 19.0).

\section{RESULTS AND DISCUSSION}

\section{Total phenolic compounds}

Phenols are very important secondary metabolite plant constituents because of their scavenging capacity on free radicals due to their hydroxyl groups $[19,20]$. Therefore, it is worthwhile to determine the total amount of phenolic content in the plant chosen for the study. The total phenolic content was determined by Folin-Ciocalteu reagent in terms of gallic acid equivalents used the regression equation of the calibration curve obtained from gallic acid $\left(y=0.001 x, R^{2}=0.991\right)$. The results showed that the $n$-butanol extract of $L$. bonduelli possesses high levels of total phenolic contents $(343 \pm 0.05 \mu \mathrm{g} / \mathrm{mg}$ ).

\section{Total flavonoids content}

Flavonoids have been identified as active constituents of medicinal plants. Due to their beneficial effects on human health, this class of compounds has received a great deal of attention, not only from the pharmaceutical industry, but also from other areas of applied 
sciences, including the food, brewing, and cosmetics industries [21]. The concentration of flavonoids in $n$-butanol extract of $L$. bonduelli was determined using the spectrophotometric method with aluminum chloride $\left(\mathrm{AlCl}_{3}\right)$. The content of flavonoids was expressed in terms of quercetin equivalents used the regression equation of the calibration curve obtained from quercetin $\left(y=0.034 x+0.015, R^{2}=0.990\right)$. Whereby the flavonoids content was $(220.5 \pm$ $0.04 \mu \mathrm{g} / \mathrm{mg})$.

The results obtained indicated that $n$-butanol extract of of $L$. bonduelli is a rich source of antioxidants, including phenols and flavonoids. In general, the higher phenolic contents resulted in higher antioxidant activity [20].

\section{DPPH radical scavenging activity}

The presence of phenolic compounds like flavonoids in the extract is probable to be responsible for the free radical scavenging activity. Phenolic compounds and flavonoids have been reported to be associated with antioxidative action in biological systems, acting as scavengers of free radicals [22]. In the present study, the free radical scavenging activity of $n$-butanol extract of $L$. bonduelli and vitamin $C$ were evaluated through their ability to quench 2, 2-diphenyl-1-picrylhydrazyl (DPPH) radical. Figure 1 illustrates a significant decrease of DPPH radical due to the scavenging ability of tested samples which correlates with a dose effect dependence. Compared to vitamin $C\left(\mathrm{IC}_{50}=5 \pm 0.1 \mu \mathrm{g} / \mathrm{mL}\right), n$-butanol extract showed a considerable scavenging activity $\left(\mathrm{IC}_{50}=14.92 \pm 0.032 \mu \mathrm{g} / \mathrm{mL}\right)$ and the highest percentage of the inhibition was $96 \%$ similar to vitamin C (Figure 1) in the same concentration $(25 \mu \mathrm{g} / \mathrm{mL})$. The presence of phenolic compounds (containing phenolic hydroxyls) are mainly found in this extract and could be attributable to the observed high antiradical properties. In this context, several authors reported that most antioxidant activities from plant sources are derived from phenolic compounds. Structurally, phenolics comprise an aromatic ring, bearing one or more hydroxyl substituent. The antioxidant activity of this kind of molecule is due to their ability to scavenge free radicals, donate hydrogen atoms or electron, or chelate metal cations [3].

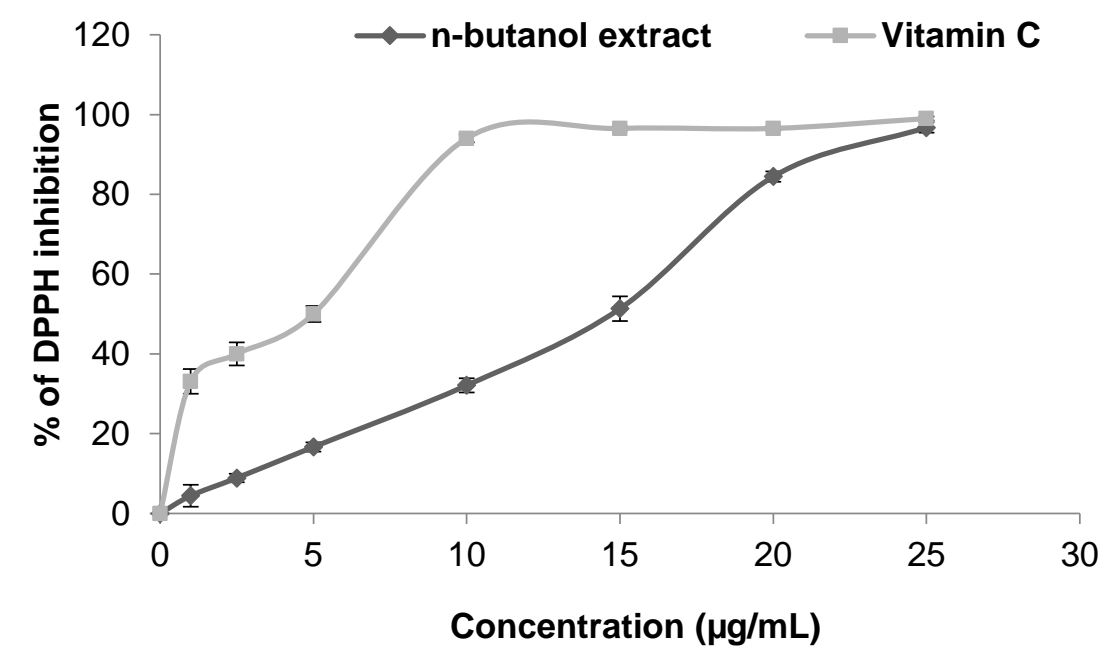

Figure 1. DPPH Scavenging activities of $n$-butanol extract of $L$. bonduelli and vitamin C. Values are mean \pm SD of three samples analyzed individually in triplicate.

\section{Inhibition of lipid peroxidation}

In biological systems, lipid peroxidation generates a number of degradation products, such as MDA, and it was considered to be an important cause of cell membrane destruction and cell damage [23]. This study measured the potential of $n$-butanol extract of $L$. bonduelli 
to inhibit lipid peroxidation in egg vitellus homogenate induced by the $\mathrm{FeSO}_{4}$ system. Clearly, the $n$-butanol extract and Vitamin $\mathrm{C}$ (standard) inhibited lipid peroxidation in a dose dependent manner as shown in Figure 2. The Vitamin $\mathrm{C}$ produced greater inhibition $\left(\mathrm{IC}_{50}=\right.$ $20 \pm 0.40 \mu \mathrm{g} / \mathrm{mL})$ as compared to the extract $\left(I_{50}=181.18 \pm 0.65 \mu \mathrm{g} / \mathrm{mL}\right)$. $n$-butanol extract of $L$. bonduelli demonstrated moderate anti-lipid peroxidative effects, which may be useful in preventing the progress of various oxidative stress related diseases such as inflammation and cancer. Phenolic compounds are majorly responsible for the antioxidant activity of plant materials [24]. Flavonoids are strong metal chelators that inhibit lipid peroxidation [25].

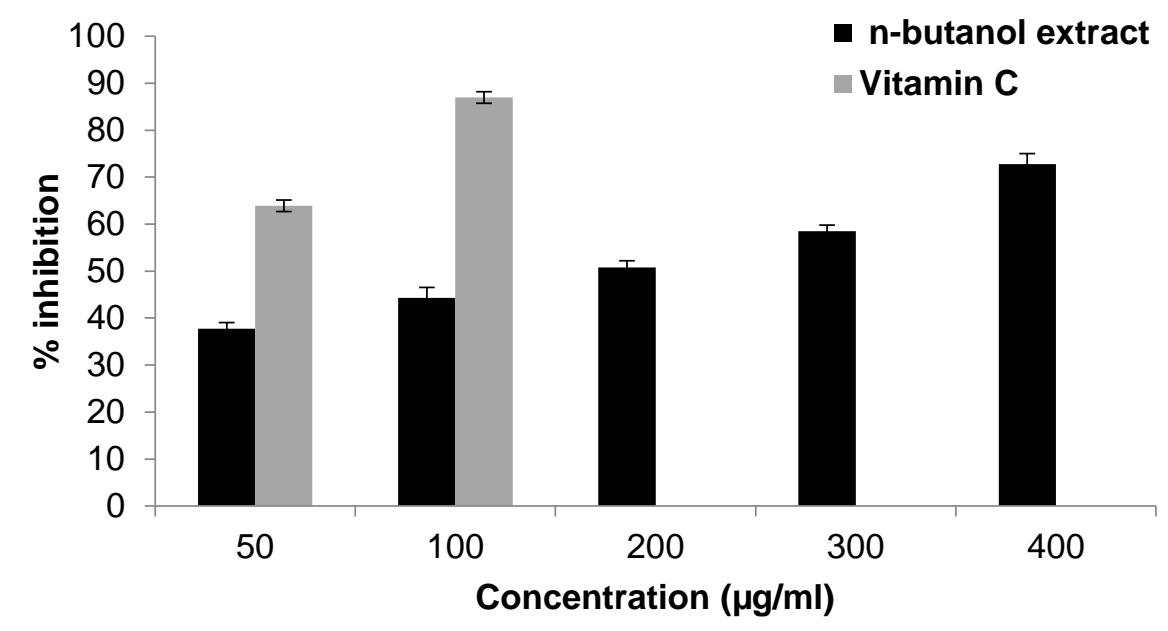

Figure 2. Inhibition by $n$-butanol extract of $L$. bonduelli and vitamin $\mathrm{C}$ of $\mathrm{FeSO}_{4}$ induced lipid peroxidation of egg vitellus. Values are expressed in terms of mean \pm SD for three observations.

\section{DNA damage inhibition efficiency}

In case of plasmid, damage of DNA results in a cleavage of one of the phosphodiester chains of the supercoiled DNA and produces a relaxed open circular form. Further cleavage near the first breakage results in linear double-stranded DNA molecules. The formation of circular form of DNA is indicative of single-strand breaks and the formation of linear form of DNA is indicative of double-strand breaks $[26,27]$. In this work we evaluate the oxidative DNA damage protective activity of $n$-butanol extract of $L$. bonduelli on DNA cleavage induced by $\mathrm{H}_{2} \mathrm{O}_{2}$ UV-photholysis using in vitro method of Russo et al. (2001) [17]. UVphotolysis of $\mathrm{H}_{2} \mathrm{O}_{2}$ generates ${ }^{\circ} \mathrm{OH}$ radicals, which cause colossal oxidative damage. ${ }^{\bullet} \mathrm{OH}$ bound to DNA leads to strand breakage, deoxysugar fragmentation, and base modification. As shown in lane 2 of Figure 3 UV-photolysis of $\mathrm{H}_{2} \mathrm{O}_{2}$ of 46966 plasmid DNA resulted in the cleavage of supercoiled to give open circular (OC DNA) and linear forms of plasmid DNA (LIN DNA), indicating that $\cdot \mathrm{OH}$ generated from UV-mediated decomposition of $\mathrm{H}_{2} \mathrm{O}_{2}$ produced both single-strand and double-strand DNA breaks. Addition of $50 \mu \mathrm{g} / \mathrm{mL}$ of $n$ butanol extract of $L$. bonduelli induced the significant reduction in the formation of open circular and linear forms and increased supercoiled or native form of plasmid DNA. The DNA cleavage analysis demonstrated the strong antioxidant properties of $L$. bonduelli. In fact, this extract suppressed the formation of linear DNA, generated by exposure of plasmid DNA to - $\mathrm{OH}$ radical generated by $\mathrm{H}_{2} \mathrm{O}_{2} \mathrm{UV}$-photolysis, and induced a partial recovery of super coiled DNA. The extract showed high phenolic content which justified the antioxidant and DNA damage inhibition properties of the plant. This result agreed with the results of many other studies suggested that phenolic compounds can protect the DNA from the oxidative damage [28-31]. The DNA damage inhibition potential of the extract could be used in cancer prevention. 
Lane 1 Lane2 Lane3

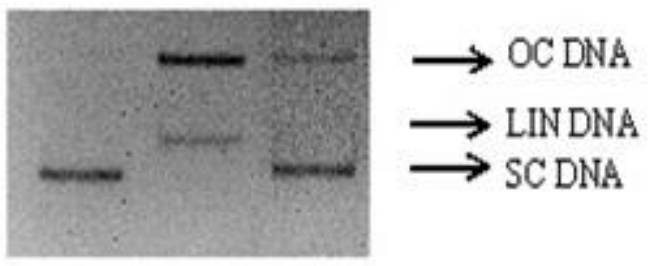

Figure 3. Effect of extract $(50 \mu \mathrm{g})$ on the protection of supercoiled DNA (46966) against oxidative damage caused by UV- photolysed $\mathrm{H}_{2} \mathrm{O}(3 \%)$. Lane 1: untreated non-irradiated DNA (control); Lane 2: UV-irradiated DNA; Lane 3: UV-irradiated, n-butanol extract treated (Lb); SC DNA: supercoiled DNA; OC DNA: open circular DNA; LIN DNA: linear DNA.

\section{Anticancer activity}

There have been many reports of plant extracts and different types of phytochemicals especially phenolic compounds as secondary metabolites from plants, which were shown to have a very effective anticancer activity [32-34]. However, anticancer investigations on $L$. bonduelli have not been studied so far. The anticancer activity of $n$-butanol extract of the aerial parts (leaves and flowers) of $L$. bonduelli against HeLa (human cervix carcinoma) and HT-29 (human colon adenocarcinoma) cells was tested using xCELLigence RTCA instrument. As shown in Figure 4 and 5, the extract exhibited different profiles on different concentrations. It has the most activity with the concentration of $250 \mu \mathrm{g} / \mathrm{mL}$ and it was about to reach to medium after $5 \mathrm{~h}$ post-treatment, while other concentrations (100 and $50 \mu \mathrm{g} / \mathrm{mL}$ ) showed less activity in a dose-dependent manner.

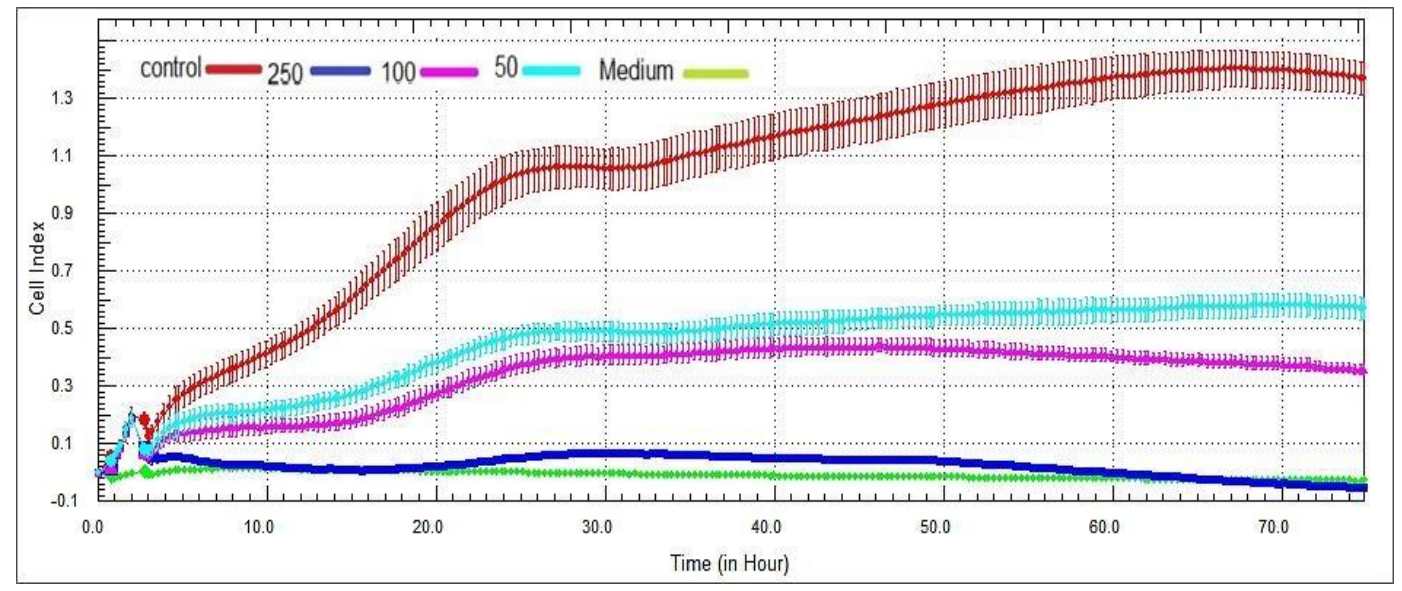

Figure 4. Anticancer activity of the $n$-butanol extract of $L$. bonduelli against HeLa cell line. Each substance was tested twice in triplicates against cell lines using XCELLigence RTCA instrument. As seen in the diagram, several extract concentrations were applied to the cells and each color represents a different concentration. 


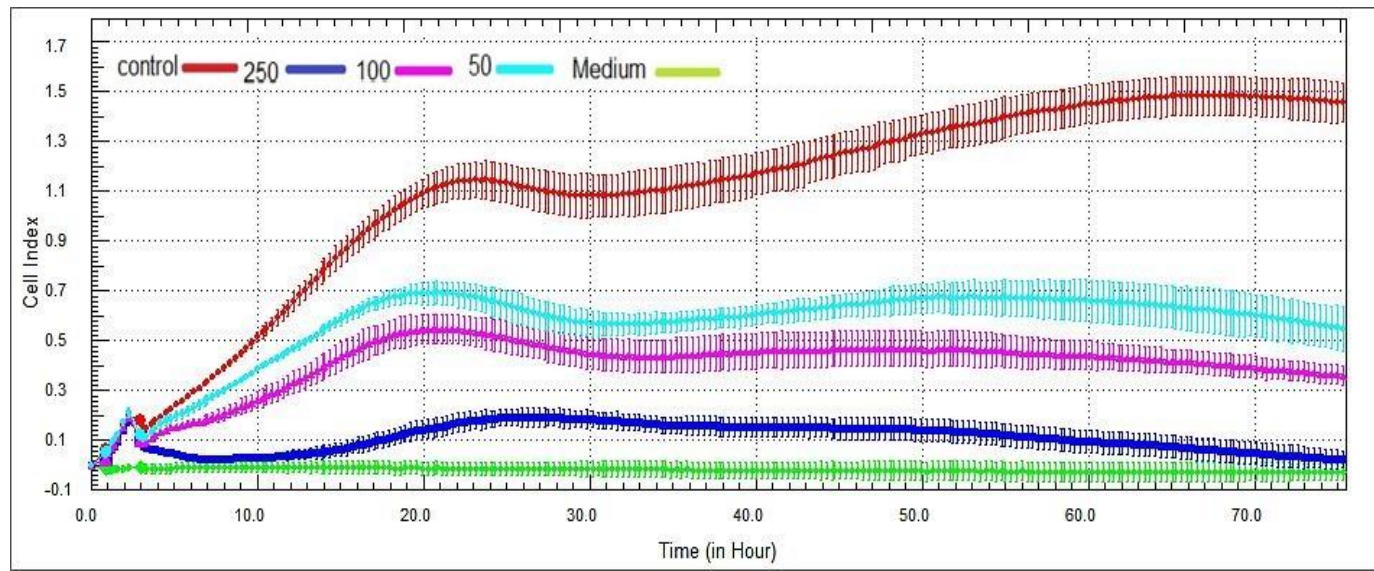

Figure 5. Anticancer activity of the $n$-butanol extract of $L$. bonduelli against HT-29 cell line. Each substance was tested twice in triplicates against cell lines using XCELLigence RTCA instrument. As seen in the diagram, several extract concentrations were applied to the cells and each color represents a different concentration.

The profiles also showed differences at different time points. Low concentrations showed better activity against HeLa cells at $15^{\text {th }} \mathrm{h}$ (Figure 4 ) and against HT-29 cells at $30^{\text {th }}$ $\mathrm{h}$ (Figure 5) after post-treatment. The results clearly show that $n$-butanol extract of L.bonduelli significantly inhibit the proliferation of cancer cells in a concentration-dependent manner during incubation for $72 \mathrm{~h}$. Moreover, the highest concentration of $n$-butanol extract of $L$.bonduelli $(250 \mu \mathrm{g} / \mathrm{ml})$ shows the highest inhibition in proliferation in all cell lines, where the inhibition was recorded as $92.6 \%$ and $98.9 \%$, for HT-29 and HeLa cells, respectively. The antioxidant, antiproliferative and DNA protective abilities of the plant extract render them suitable to be considered as a source for the development of anti-cancer drugs. The antioxidant properties of the extract might prevent cancer progression; while the DNA protection property might hold good in inhibiting secondary mutations in progressive tumor tissues [35].

\section{CONCLUSION}

These experimental results provide the basis for the development of promising natural anticancer agents possessing antioxidant activity and supporting the potential use of $n$ butanol extract of $L$. bonduelli in the pharmaceutical and manufacturing industries. Further investigations are required to understand the possible mechanism(s) of action of the extract on various cancer cells and isolation of active phytochemicals. In vivo studies are needed to confirm the pharmacological efficacy and safety of $L$. bonduelli extract.

\section{Conflicts of Interest}

The authors declare no conflict of interest.

\section{REFERENCES}

1. Aruoma, O.I. Methodological consideration for characterization for potential antioxidant actions of bioactive components in plants foods. Mutat Res 2003, 532, 9-20.

2. Singh, R.; Devi, S.; Gollen, R. Role of free radical in atherosclerosis, diabetes and dyslipidaemia: larger-than-life. Diabetes Metab Res Rev 2015, 31, 113-26. 
3. Działo, M.; Mierziak, J.; Korzun ,U.; Preisner, M.; Szopa, J.; Kulma, A. The potential of plant phenolics in prevention and therapy of skin disorders. Int J Mol Sci 2016, 17(2), 160.

4. Lobo, V.; Patil, A.; Phatak, A.; Chandra, N. Free radicals, antioxidants and functional foods: Impact on human health. Pharmacogn Rev 2010, 4, 118-126.

5. Duraipandiyan, V.; Ayyanar, M.; Ignacimuthu, S. Antimicrobial activity of some ethno medicinal plants used by Paliyar tribe from Tamil Nadu, India. BMC Compl Altern Med 2006, 6, 35.

6. Pandey, K.B.; Rizvi, S.I. Plant polyphenols as dietary antioxidants in human health and disease. Oxid Med Cell Longev 2009, 2, 270-278.

7. Medini, F.; Bourgou, S.; Lalanc, KG.; Snoussi, M.; Mkadmini, K.; Coté, I.; Abdelly, C.; Legault,J, Ksouri ,R. Phytochemical analysis, antioxidant, anti-inflammatory, and anticancer activities of the halophyte Limonium densiflorum extracts on human cell lines and murine macrophages. $S$. Afr. J. Bot 2015, 99, 158-164.

8. Rodrigues, M.J.; Neves ,V.; Martins, A.; Rauter, A.P.; Neng, N.R.; Nogueira, J.M.; Varela, J.; Barreira, L.; Custódio, L. In vitro antioxidant and anti-inflammatory properties of Limonium algarvense flowers' infusions and decoctions: A comparison with green tea (Camellia sinensis). Food Chem 2016, 200, 322-9.

9. Nostro, A.; Filocamo, A.; Giovannini, A.; Catania, S.; Costa, C.; Marino, A.; Bisignano, G. Antimicrobial activity and phenolic content of natural site and micropropagated Limonium avei (De Not) Brullo and Erben plant extracts. Nat Prod Res 2012, 26, 2132-6.

10. Tang, X.H.; Gao, J.; Chen, J.; Xu, L.Z.; Tang, Y.H.; Zhao, X.N.; Michael, L. Mitochondrial modulation is involved in the hepatoprotection of Limonium sinense extract against liver damage in mice. $J$ Ethnopharmacol 2008, 120, 427-31.

11. Yang, M.H.; Kim, N-H.; Heo, J-D.; Sung, S.H.; Jeong.; E.J. Hepatoprotective effects of Limonium tetragonum, edible medicinal halophyte growing near seashores. Pharmacogn Mag 2014, 10, S563-S568.

12. Benaissa, O., Amrani, A.; Bicha, S.; Zama, D.; Benayache, F.; Marchioni, E.; Benayache, S. Free radical scavenging action of phenolic compounds from Limonium bonduelli (Plumbaginaceae). Der Pharmacia Lettre 2013, 5, 234-240.

13. Singleton, V.L.; Orthofer, R.; Lamuela-Raventos, R.M. Analysis of total phenols and other oxidation substrates and antioxidants by means of Folin-Ciocalteu reagent In: Packer $L$, editor Methods in enzymol: oxidant and antioxidants (part A), 299 San Diego, CA: Academic Pres, 1999; $152-78$.

14. Wang, H., Gao, X.D.; Zhou, G.C.; Cai, L.; Yao, W.B. In vitro and in vivo antioxidant activity of aqueous extract from Choerospondias axillaris fruit. Food Chem 2008,106, 888-895.

15. Braca. A.; DE Tommasi, N.; Di Bari, L.; Pizza, C.; Politi, M.; Morelli, I. Antioxidant principales from Bauhinia terapotensis. J Nat Prod 2001, 64, 892-895.

16. Cao, U.; Ikeda, I. Antioxidant activity and antitumor activity (in vitro) of xyloglucan selinious ester and surfated xyloglucan. IntJ Biol Macromol 2009, 45, 231-235.

17. Russo, A.; Izzo, A.A.; Cardile, V.; Borrelli, F.; Vanella, A. Indian medicinal plants as antiradicals and DNA cleavage protectors. Phytomedicine 2001, 8, 125-132. 
18. Boussaha ,S.; Bekhouche, K.; Boudjerda, A.; León, F.; Koldas, S.; Yaglioglu, A.S.; Demirtas, I.; Brouard, I.; Marchioni, E.; Zama, D.; Benayache, S.; Benayache, F. Chemical constituents, in vitro antioxidant and antiproliferative activities of Perralderia coronopifolia Coss. Subsp. eucoronopifolia. M. var. typica M. extract. Rec. Nat. Prod 2015, 9, 312-322.

19. Khalili, R.M.A.; Shafekh, S.E.; Norhayati, A.H.; Mohd Fatahudin, I.; Rahimah, R., Norkamaliah, $\mathrm{H}$.; Nor Azimah, A. Total phenolic content and in vitro antioxidant activity of winged bean (Psophocarpus tetragonolobus). Pak J Nutr 2013, 12, 416 -422.

20. Keffous, F.; Belboukhari, N.; Sekkoum, K.; Djaradi, H.; Cheriti, A.; Aboul-Enein, H.Y. Determination of the antioxidant activity of Limoniastrum feei aqueous extract by chemical and electrochemical methods. Cogent Chemistry 2016, 2, 1186141.

21. Marín, M.; Máñez, S. Recent trends in the pharmacological activity of isoprenyl phenolics. Curr Med Chem 2013, 20, 272-9.

22. Kolli, D.; Amperayani, K.R.; Parimi, U.Total phenolic content and antioxidant activity of Morinda tinctoria leaves. Indian J Pharm Sci 2015, 77, 226-230.

23. Lizcano, L.J., Viloria-Bernal, M.;Vicente, F.; Berrueta, L.A.; Gallo, B.; Martínez-Cañamero, M.; Ruiz-Larrea, M.B.; Ruiz-Sanz, J.I. Lipid oxidation inhibitory effects and phenolic composition of aqueous extracts from medicinal plants of colombian Amazonia. Int J Mol Sci 2012, 13, 54545467.

24. Zhao, H.; Zhang, H.; Yang, S. Phenolic compounds and its antioxidant activities in ethanolic extracts from seven cultivars of Chinese Jujube. Food Science and Human Wellness 2014, 3, 183-190.

25. Geethaa, S.; Kedlayab, R.; Vasudevanc, D.M. Inhibition of lipid peroxidation by botanical extracts of Ocimum sanctum: In vivo and in vitro studies. Life Sciences 2004, 76, 21-28.

26. Burrows, C.J.; Muller, J.G. Oxidative Nucleobase Modifications Leading to Strand Scission. Chem Rev 1998, 98, 1109-1152.

27. Singh, B.N.; Singh, B.R.; Singh, R.L.; Prakash, D., Dhakarey, R.; Upadhyay, G.; Singh, H.B. Oxidative DNA damage protective activity, antioxidant and anti-quorum sensing potentials of Moringa oleifera. Food Chem Toxicol 2009, 47, 1109-16.

28. Arora, R.; Dhaker, A.S.; Adhikari, M.; Sharma, J.; Chawla, R.; Gupta, D.; Zheleva, A.; Karamalakova, Y.; Kumar, R.; Sharma, R.K.; Sharma, A.; Sultana, S.; Sharma, R.K.; Tripathi, R.P.; Gadjeva, V. Radical scavenging and radiomodulatory effects of Psoralea corylifolia Linn substantiated by in vitro assays and EPR spectroscopy. Z Naturforsch C 2011, 66, 35-46.

29. Guha, G.; Rajkumar, V.; Mathew, L.; Kumar, R.A. The antioxidant and DNA protection potential of Indian tribal medicinal plants. Turk J Biol 2011, 35, 233-242.

30. Verma, K.; Shrivastava, D.; Kumar, G. Antioxidant activity and DNA damage inhibition in vitro by a methanolic extract of Carissa carandas (Apocynaceae) leaves. J Taibah Univ Sci 2015, 9, 34-40.

31. Seo, K.H.; Lee, J.Y., Debnath, T.; Kim ,Y.M.; Park, J.Y.; Kim, Y.O.;Park, S.J.; Lim, B.O. DNA Protection and Antioxidant Potential of Chestnut Shell Extracts. J Food Biochem 2016, 40, 20 30. 
32. Kuete, V., Mbaveng, A.T.; Zeino, M.; Fozing, C.D.; Ngameni, B.; Kapche, G.D.W.F., Ngadjui, B.T.; Efferth, T. Cytotoxicity of three naturally occurring flavonoid derived compounds (artocarpesin, cycloartocarpesin and isobavachalcone) towards multi-factorial drug-resistant cancer cells. Phytomedicine 2015, 22, 1096-1102.

33. Al-Oqail, M.M.; Siddiqui, M.A.; Al-Sheddi, E.S.; Saquib, Q.; Musarrat, J.; Al-Khedhairy, A.A.; Farshori, N.N. Verbesina encelioides: cytotoxicity, cell cycle arrest, and oxidative DNA damage in human liver cancer (HepG2) cell line. BMC Complement Altern Med 2016, 16, 126.

34. Pollio. A.; Zarrelli, A.; Romanucci, V.; Di Mauro, A.; Barra, F.; Pinto, G.; Crescenzi, E.; Roscetto, E.; Palumbo, G. Polyphenolic Profile and Targeted Bioactivity of Methanolic Extracts from Mediterranean Ethnomedicinal Plants on Human Cancer Cell Lines. Molecules 2016, 21, 395.

35. Rajkumar, V.; Guha, G.; Kumar, A. Antioxidant and anti-cancer potentials of Rheum emodi rhizome extracts. J Evid Based Complementary Altern Med 2011, 2011, 697986. BY NC) license (http://creativecommons.org/licenses/by/4.0/).

\footnotetext{
*Correspondence: amrani.a@umc.edu.dz; Tel.: +21331811103
} 